Abstracta Iranica Abstracta Iranica

Revue bibliographique pour le domaine irano-aryen

Volume 40-41 | 2019

Comptes rendus des publications de 2017-2018

\title{
Firoze Kotwal. « A Historical Overview of the Parsi Settlement in Navsari and Its Rise as the Bastion of Zoroastrianism »
}

Samra Azarnouche

\author{
(2) OpenEdition \\ Journals \\ Édition électronique \\ URL : http://journals.openedition.org/abstractairanica/50847 \\ DOI : 10.4000/abstractairanica. 50847 \\ ISBN : 1961-960X \\ ISSN : 1961-960X \\ Éditeur : \\ CNRS (UMR 7528 Mondes iraniens et indiens), Éditions de l'IFRI
}

\section{Référence électronique}

Samra Azarnouche, «Firoze Kotwal. «A Historical Overview of the Parsi Settlement in Navsari and Its Rise as the Bastion of Zoroastrianism » », Abstracta Iranica [En ligne], Volume 40-41 | 2019, document 11, mis en ligne le 30 décembre 2019, consulté le 26 avril 2021. URL : http://journals.openedition.org/ abstractairanica/50847 ; DOI : https://doi.org/10.4000/abstractairanica.50847

Ce document a été généré automatiquement le 26 avril 2021.

Tous droits réservés 


\title{
Firoze Kotwal. «A Historical Overview of the Parsi Settlement in Navsari and Its Rise as the Bastion of Zoroastrianism »
}

\author{
Samra Azarnouche
}

\section{RÉFÉRENCE}

Firoze Kotwal. «A Historical Overview of the Parsi Settlement in Navsari and Its Rise as the Bastion of Zoroastrianism », Dabir, vol. 1.4, 2017, p. 63-72

1 Dans ce discours inaugural des célébrations du $140^{\mathrm{e}}$ anniversaire de la First Dastoor Meherji Rana Library de Navsari, l'A. retrace l'histoire de la communauté zoroastrienne et des institutions religieuses parsies de cette ville depuis l'arrivée des membres de la Khorāsāni Maṇdali ou la congrégation du Khorāsān (stèle datée de 1081) et du premier prêtre, Kāmdīn Zartōšt, en 1142, jusqu'à la consécration de l'Ātash Bahrām en 1765 par le Dastur Meherji Rana. Les rivalités entre prêtres pour la conservation de certaines prérogatives rituelles, notamment les conflits meurtriers entre les Sanjānā et les Bhagariā, sont également décrits et, tout comme l'ensemble de l'article, documenté avec une grande précision. 


\section{AUTEURS}

\section{SAMRA AZARNOUCHE}

EPHE, Mondes iranien et indien, Paris 